\title{
FERTILISATION SOURCE AND DOSE OPTIMISATION BOOST YIELD OF DURUM WHEAT IN MEDITERRANEAN CLIMATIC CONDITIONS
}

\author{
Mazlum AYHAN ${ }^{1}$, Ferhat KIZILGEÇi' ${ }^{2, *}$, Muhammad Aamir IQBAL ${ }^{3}$ \\ *E-mail: ferhatkizilgeci@artuklu.edu.tr
}

Received: Nov. 20, 2021. Revised: Dec. 06, 2021. Accepted: Dec. 12, 2021. Published online: Dec. 23, 2021

\begin{abstract}
Climate change, global warming, environmental pollution, greenhouse gas emissions from agricultural fields, stagnant wheat yields and reduced farm economic returns require optimisation of sources and doses of plant nutrients. A field study was conducted to evaluate wheat response to different forms of fertilisers and nitrogen $(\mathrm{N})$ doses under Mediterranean conditions. The field trial was comprised of fertiliser sources, including chemical fertilisers, compost and leonardite, while different nitrogen levels $\left(0,80,160,240 \mathrm{~kg} \mathrm{ha}^{-1}\right)$ were also tested. The experimental variables included yield attributes (height of the, length of the spike, spikelets number per spike, thousand-grain weight and grain yield). In addition, nutritional quality attributes like protein and starch contents were studied along with NDVI values of wheat under different fertilisation regimes. The trial was executed using a randomised complete block (factorial) design using four replications. The results revealed that
\end{abstract}

fertiliser forms and $\mathrm{N}$ doses remained ineffective for boosting yield attributes of wheat. For nutritional characteristics of wheat grains, a higher $\mathrm{N}$ dose remained instrumental in boosting protein, starch and wet gluten contents. Thus, $240 \mathrm{~kg} \mathrm{ha}^{-1}$ of $\mathrm{N}$ dose might be recommended for general adoption under Mediterranean conditions; however, study findings are limited in scope and further in-depth studies are needed by testing organic manures from plant and animal origins.

Keywords: compost; leonardite; NDVI; nitrogen doses; protein content.

\section{INTRODUCTION}

The changing climate scenario has threatened the food security of the masses by reducing productivity, deteriorating nutritional quality, slashing economic returns and imparting unsustainability to staple crop production globally (Chowdhury et al.,

\footnotetext{
${ }^{1}$ Mardin Artuklu University, Institute of Graduate Education, Department of Field Crops, Mardin, Turkey

2 Mardin Artuklu University, Kiziltepe Vocational School, Department of Plant and Animal Production, Mardin, Turkey

3 University of Poonch Rawalakot, Faculty of Agriculture, Department of Agronomy, AJK, Pakistan
} 
2021; Iqbal et al., 2021a). Most of the staple crops like wheat entail a C-3 metabolic pathway, which gets abruptly disturbed with dynamic growth conditions. Wheat occupies a pivotal position among staple crops and ranks second after rice in terms of production $(26 \%)$ and area under cultivation (31\%) (Alghawry et al., 2021; lqbal et al., 2021b; Ahmad et al., 2021). Likewise, durum wheat is being grown on $50 \%$ of the cultivated area and is $70 \%$ of the cereal planted in Turkey (Yazar and Karadogan, 2018). Durum wheat is tetraploid and quite different from hexaploid bread wheat in terms of quality characteristics and utilisation.

Besides changing climate, suboptimal fertilisation has contributed significantly to stagnation and even reduction of durum wheat yield (Siddiqui et al 2019; Alam et al., 2021). Inorganic fertilisers used as a sole source of plant nutrients have not only contributed to environmental pollution, but also resulted in yield stagnation during the last decade (Uyanöz et al., 2004). Additionally, the rapid multiplication of the human population and construction of human settlements have decreased the availability of agricultural lands, which have multiplied the need to boost productivity per unit of land area. In a similar fashion to chemical fertilisers, organic manures lack reorganisation, due to a decline in yield, in comparison to chemical fertilisers (lqbal et al., 2021b). Global warming and climate change have further necessitated sorting out the most superior sources of organic manures and optimising their doses to produce comparable yields (Siddiqui et al., 2019). Previously, it was inferred that co-application of organic manures with reduced doses of chemical fertilisers affected growth attributes, and ultimately higher wheat yield was obtained. However, the findings of this field study are limited in scope, owing to the testing of a limited number of organic manures and wheat cultivars (Zahoor et al., 2021). Similarly, organic manures from plant origin are applied in conjunction with humic acid using the rate of 0.625 tons and $10 \mathrm{~kg}$, respectively, per hectare significantly promoted yield attributes of wheat (Alghawry et al., 2021). Similarly, organic manures applied in conjunction with chemical fertilisers were evaluated for eleven winter wheat cultivars and integrated regimes (organic manures applied with reduced doses of chemical fertilisers) could potentially produce comparable grain yield of wheat; however, it was suggested to test manure combinations under varying pedo-climatic conditions before recommending for general adoption (lqbal et al., 2021). Moreover, numerous other factors favour finding alternate sources of plant nutrition, such as chemical fertilisers, induced deterioration of the soil structure and eutrophication (Sullivan et al., 1998). Organomineral fertilisers are fertilisers obtained because of the combination or reaction of single, double or triple plant nutrients with one or more organic products. Organic fertilisers consist of residues or wastes of plant, animal and human origin. Organic 
fertilisers are mostly used to improve the soil properties both physical, chemical and biological. Namlı et al. (2019) found that it is important to evaluate the organic materials in wheat cultivation as organomineral fertiliser, organic soil conditioner and K-humate-humic acid by content analysis. They are stabilised, mineralised products of various organic substances that can be biochemically decomposed by organisms. It becomes evident that considerable research and knowledge gaps exist regarding organic manure source and dose optimisation under Mediterranean conditions, while chemical fertilisers induced pollution and wheat yield stagnation require conducting in-depth studies.

The research hypothesis of this trial was that organomineral fertilisers might perform better than chemical fertilisers in terms of wheat yield and nutritional quality, owing to the slow and steady provision of multiple nutrients in sufficient quantities. Thus, this field study aimed to evaluate three different fertiliser forms, including organomineral fertiliser (compost and leonardite) and chemical fertiliser, as well as four different nitrogen levels $\left(0,80,160,240 \mathrm{~kg} \mathrm{~N} \mathrm{ha}^{-1}\right)$ for their effects on grain yield, yield components and quality characteristics.

\section{MATERIALS AND METHODS}

The research trial was conducted in a rain-fed environment from the 2019-2020 growing season in Mardin, Turkey $\left(37^{\circ} 10^{\prime} 2108^{\prime \prime} \mathrm{N}, 40^{\circ} 34^{\prime} 0255^{\prime \prime} \mathrm{E}\right.$ and $475 \mathrm{~m}$ elevation). For the soil analysis, samples were taken from $0-30 \mathrm{~cm}$ depth from four corners and the middle of the experimental block to determine the physicochemical features of the experimental soil. The soil texture was clayey-loamy and organic matter content was low (1.86\%). In addition, the amount of available phosphorus was $1.36 \mathrm{~kg} \mathrm{ha}^{-1}$ and $\mathrm{EC}$ remained $0.049 \%$ along with a $\mathrm{pH}$ of 7.57. The 'Burgos' variety of wheat, which is widely cultivated in the region, was used as planting material in the study. Chemical and organomineral fertilisers (compost and leonardite) were used as fertilisers. The properties of leonardite and compost-based organomineral fertilisers are given in Table 1. Chemical fertilisers were applied as diammonium phosphate (DAP) using the rate of $18 \% \mathrm{~N}$ and $46 \% \mathrm{P}_{2} \mathrm{O}_{5}$

The study used a four-replication randomised complete block (factorial) design. Fertiliser forms were included in the main plots, and nitrogenous fertiliser levels $\left(0,80,160\right.$ and $\left.240 \mathrm{~N} \mathrm{~kg} \mathrm{ha}^{-1}\right)$ were included in the subplots. In the experiment, experimental units were $1.2 \mathrm{~m}$, and parcel areas were $4.8 \mathrm{~m}^{2}$. All of the phosphorus fertiliser was applied at $80 \mathrm{~kg} \mathrm{ha}^{-1}$ together with planting. In the control applications where nitrogen was not applied, phosphorous was applied as triple superphosphate. Half of the total nitrogen amount determined for each plot was given as base fertiliser with planting, and the remaining half was given as top fertiliser in the tillering period.

The daily temperature and precipitation values of the study location are given in Fig. 1 and Fig. 2.

\section{Experimental variables}

As already stated, different yield attributes were recorded by following standard methodologies. In addition, grain quality characteristics including protein, starch and wet gluten contents were estimated. Furthermore, the normalised vegetation index (NDVI) was determined 
with the help of a Trimble brand GreenSeeker instrument. NDVI measurements were taken between 12:00 and 14:00 during clear weather.

\section{Statistical analysis}

Values obtained from the study were analysed by using the JMP 10 Statistical package program according to a four replication randomised complete block (factorial) design. The differences between the mean values of fertiliser forms and nitrogen doses were subjected to the Tukey test at the 5\% level.

Table 1 - Content values of organomineral (leonardite and compost) fertilisers used in the research

\begin{tabular}{lllll}
\hline \multirow{2}{*}{ Fertiliser content } & \multicolumn{2}{l}{ Leonardite } & \multicolumn{2}{c}{ Compost } \\
\cline { 2 - 5 } & $\begin{array}{l}\text { Base } \\
\text { fertiliser }\end{array}$ & $\begin{array}{l}\text { Top } \\
\text { fertiliser }\end{array}$ & $\begin{array}{l}\text { Base } \\
\text { fertiliser }\end{array}$ & $\begin{array}{l}\text { Top } \\
\text { fertiliser }\end{array}$ \\
\hline Total organic matter & $15 \%$ & $10 \%$ & $20 \%$ & $20 \%$ \\
\hline Total nitrogen $(\mathrm{N})$ & $8 \%$ & $25.50 \%$ & $8 \%$ & $24 \%$ \\
\hline Ammonium nitrogen $\left(\mathrm{N}^{\left.-\mathrm{NH}_{4}\right)}\right.$ & $8 \%$ & $10 \%$ & $8 \%$ & - \\
\hline Urea nitrogen $(\mathrm{N})$ & - & $16 \%$ & - & $23 \%$ \\
\hline Organic nitrogen $(\mathrm{N})$ & - & - & - & $1 \%$ \\
\hline Total $\mathrm{P}_{2} \mathrm{O}_{5}$ & $20 \%$ & - & $21 \%$ & - \\
\hline Water-soluble $\mathrm{P}_{2} \mathrm{O}_{5}$ & $18 \%$ & - & $16 \%$ & - \\
\hline Total $\mathrm{SO}_{3}$ & $10 \%$ & - & $15 \%$ & - \\
\hline Water soluble sulphur trioxide $\left(\mathrm{SO}_{3}\right)$ & - & $20 \%$ & - & - \\
\hline Water-soluble magnesium oxide $(\mathrm{MgO})$ & - & - & - & $2 \%$ \\
\hline Total (humic \& fulvic) & $10 \%$ & $5 \%$ & $7 \%$ & $10 \%$ \\
\hline Water soluble iron $(\mathrm{Fe})$ & - & - & - & $0.5 \%$ \\
\hline Zinc total $(\mathrm{Zn})$ & - & - & $0.20 \%$ & \\
\hline Maximum humidity & $20 \%$ & $2 \%$ & - & $20 \%$ \\
\hline pH range & $6-8$ & $4-6$ & - & $6-8$ \\
\hline
\end{tabular}

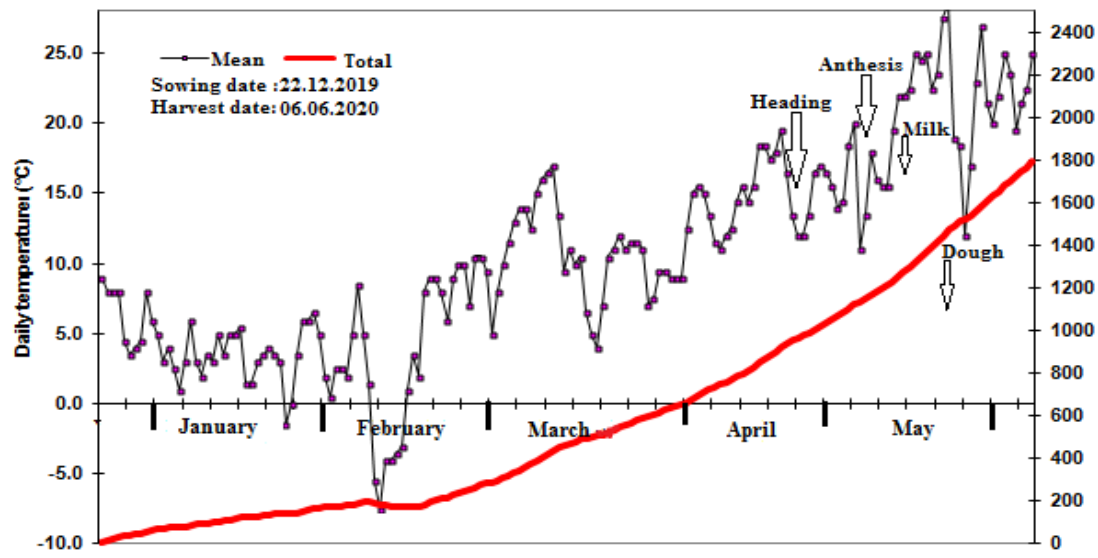

Figure 1 - Daily and total temperature values for the period in which the research was conducted 


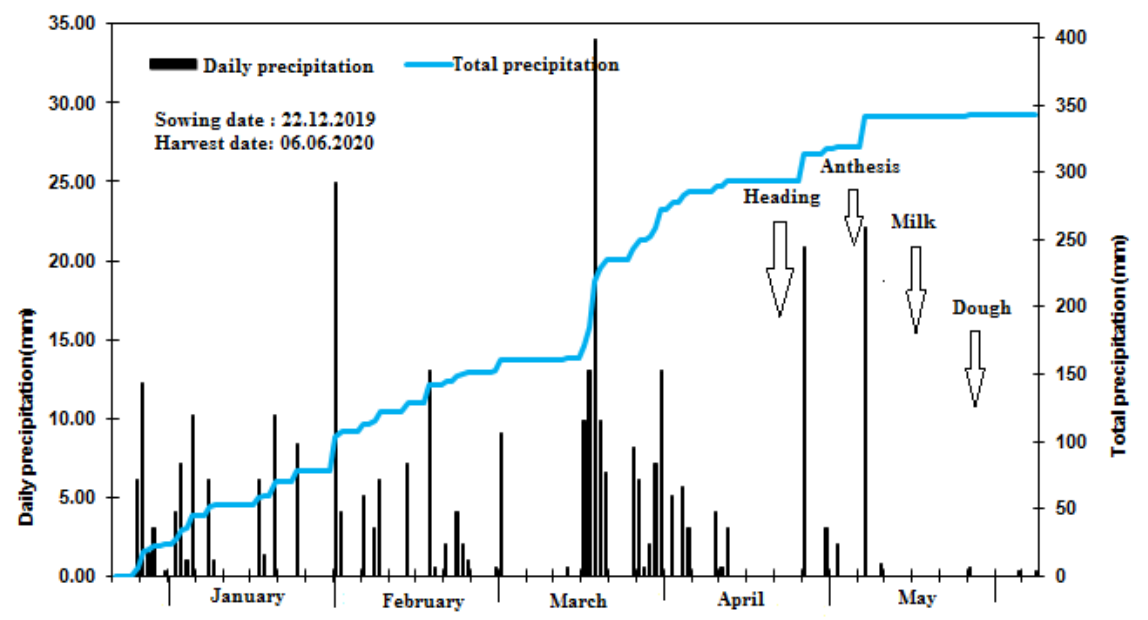

Figure 2 - Daily and total precipitation values for the period in which the research was conducted

\section{RESULTS AND DISCUSSION}

\section{Agronomic characteristics}

\section{Plant height}

Fertiliser form, nitrogen dose and the fertiliser form $\times$ nitrogen dose interaction were found to be statistically insignificant (Table 2). The highest plant height was obtained from the $160 \mathrm{~kg} \mathrm{~N} \mathrm{ha}{ }^{-1}$ leonardite application $(91.23 \mathrm{~cm})$. The lowest plant height value was determined from the application of compost $240 \mathrm{~kg} \mathrm{~N} \mathrm{ha}{ }^{-1}(87.68 \mathrm{~cm})$ (Table 3). Similar to our research, Kizilgeci et al. (2021) found that the effects of nitrogen doses on plant height were statistically insignificant; while in contradiction, Özseven (1995) reported that increasing $\mathrm{N}$ doses had a considerable impact on the height of the plants and that higher $\mathrm{N}$ doses boosted photosynthesis rate from higher chlorophyll contents. This led to the greater partition of assimilates from leaves towards sinks such as stems and taller plants were ultimately observed.

\section{Spike length}

Like plant height, fertiliser form, nitrogen dose and the fertiliser form $x$ nitrogen dose interaction remained statistically insignificant for spike length of wheat (Table 2). Spike length varied between 6.50 and $6.93 \mathrm{~cm}$ (Table 3). However, the highest spike length value $(6.93 \mathrm{~cm})$ was obtained from the application of the chemical fertilisers at a rate of $160 \mathrm{~kg} \mathrm{~N} \mathrm{ha}^{-1}$, while the control treatment had the lowest spike length $(6.50 \mathrm{~cm})$ (Table 3).

In agreement with our findings, Kizilgeci et al. (2021) stated that the effects of nitrogen doses on spike length were statistically insignificant, while contrarily, Özseven (1995) reported a significant effect of fertiliser forms and increasing $\mathrm{N}$ doses on length of spikes. 
Table 2 - Analysis of variance (mean squares) for some yield attributes with different fertiliser forms and nitrogen dose applications to durum wheat

\begin{tabular}{lllll}
\hline Source & Df & Plant height & Spike length & Number of spikelets \\
\hline Replication & 3 & 16.1924 & 0.3164 & 0.8025 \\
\hline FF & 2 & 2.2565 & 0.0131 & 0.0565 \\
\hline $\mathrm{N}$ & 3 & 4.2935 & 0.0647 & 0.2714 \\
\hline FF $\times$ N & 6 & 3.8981 & 0.0687 & 0.1328 \\
\hline Error & 33 & 5.58 & 2.43 & 4.18 \\
\hline CV $(\%)$ & & 2.65 & 4.05 & 2.12 \\
\hline
\end{tabular}

FF: Fertiliser form, N: Nitrogen dose, CV: coefficient of variation

Table 3 - Average values of some yield attributes with different fertiliser forms and nitrogen doses applied to durum wheat

\begin{tabular}{lllllllllllll}
\hline $\begin{array}{l}\text { N Doses } \\
\text { (kg ha }^{-1} \text { ) }\end{array}$ & \multicolumn{4}{l}{ Plant height $(\mathbf{c m})$} & \multicolumn{4}{c}{ Spike length $(\mathbf{c m})$} & \multicolumn{4}{c}{ Number of spikelets } \\
\hline 0 & Co & Le & Mean & Ch & Co & Le & Mean & Ch & Co & Le & Mean \\
\hline 80 & 88.78 & 89.88 & 7.88 & 8.84 & 6.50 & 6.73 & 6.60 & 6.61 & 16.70 & 16.80 & 16.48 & 16.48 \\
\hline 160 & 90.08 & 89.10 & 89.80 & 89.33 & 6.60 & 6.78 & 6.58 & 6.65 & 16.68 & 16.95 & 16.88 & 16.88 \\
\hline 240 & 90.00 & 89.08 & 91.23 & 90.10 & 6.93 & 6.75 & 6.65 & 6.78 & 16.88 & 17.18 & 16.93 & 16.93 \\
\hline Mean & 89.00 & 87.68 & 89.80 & 88.83 & 6.73 & 6.60 & 6.80 & 6.72 & 16.70 & 16.50 & 16.90 & 16.90 \\
\hline
\end{tabular}

Ch: Chemical, Co: Compost, Le: Leonardite

\section{Spikelets number in spike}

Following the trend of plant height and spike length, the spikelets number in spike remained on par with each other for all treatments (Table 2). The number of spikelets varied between 16.48-16.95. The highest number of spikelets was obtained from the leonardite $0 \mathrm{~kg} \mathrm{~N} \mathrm{ha-1}$ application (16.48). The least number of spikelets was determined from the $80 \mathrm{~kg} \mathrm{~N} \mathrm{ha}{ }^{-1}$ compost application (16.95) (Table 3). Similar to our study, Kizilgeci (2019) inferred that $\mathrm{N}$ doses and fertilisers form were of secondary importance, while phosphorous (P) content imparted comparative superiority to wheat cultivars in terms of spikelets per spike. Contrarily, Başar et al. (1998) reported that $\mathrm{N}$ doses remained effective in increasing the number of spikelets, due to the greater portioning of assimilates towards reproductive parts of wheat, and better yield attributes were ultimately recorded. Previously, it has also been reported that the number of spikelets in wheat was greatly affected by environmental factors and the genetic potential of the cultivars (Erekul et al., 2005). In addition, it was inferred that the number of spikelets per spike decreased significantly due to nutrient deficiency and drought spells (Öztürk and Korkut, 2018).

\section{Grain number per spike}

Practically, the number of grains in the spike was not influenced by the interaction between the nitrogen dose and the fertilizer format $\times$ the nitrogen dose. (Table 4). The grains number in spike for each application ranged 
45.15-49.78. The highest grain number per spike (49.78) was recorded for the leonardite $\left(160 \mathrm{~kg} \mathrm{~N} \mathrm{ha}^{-1}\right)$ application, while the lowest number of grains per spike (45.15) was obtained at the dose of $240 \mathrm{~kg} \mathrm{~N} \mathrm{ha}{ }^{-1}$ chemical fertiliser (Table 5).

Similar to our research, Gökmen et al. (2008) stated that the effects of nitrogen doses on the grain number per spike were statistically insignificant, while many researchers reported that the effects of nitrogen doses on the grain number per spike were statistically significant (Kara, 2013). The number of grains per spike was inferred to be a feature that was more influenced by genetics, compared to agronomic practices.

\section{Weight of the grain in spike}

The weight of the grain is one of the most important yield attributes and can used as a reliable indicator to estimate the grain yield of wheat. Like other yield attributes, grain weight also remained unaffected by fertiliser form, $\mathrm{N}$ dose and fertiliser form $\times \mathrm{N}$ dose (Table 4). Grain weight per spike varied between 1.96-2.23 g. The highest weight of the grain in spike was registered at the dose of $160 \mathrm{~kg} \mathrm{~N} \mathrm{ha}^{-1}$ leonardite application $(2.23 \mathrm{~g})$. The lowest weight of the grain in ear was determined in the dose of $240 \mathrm{~kg} \mathrm{~N} \mathrm{ha}^{-1}$ chemical fertilizer (1.96 g) (Table 5).

Table 4 - Analysis of variance (mean squares) for grain number and weight with different fertiliser forms and nitrogen dose applications to durum wheat

\begin{tabular}{llll}
\hline Source & Df & $\begin{array}{l}\text { Number of grain } \\
\text { in spike }\end{array}$ & Weight of the grain $(\mathbf{g})$ \\
\hline Replication & 3 & 29.4425 & 0.0773 \\
\hline $\mathrm{FF}$ & 2 & 10.9144 & 0.0311 \\
\hline $\mathrm{N}$ & 3 & 8.2764 & 0.0307 \\
\hline $\mathrm{FF} \times \mathrm{N}$ & 6 & 6.9641 & 0.0166 \\
\hline Error & 33 & 224.3 & 1.1 \\
\hline $\mathrm{CV}(\%)$ & & 5.49 & 8.8 \\
\hline
\end{tabular}

FF: Fertiliser form, N: Nitrogen dose, CV: coefficient of variation

Table 5 - Average values of number of grain in spike, grain weight in different fertiliser forms and nitrogen doses application to durum wheat

\begin{tabular}{lllllllll}
\hline $\begin{array}{l}\text { N Doses } \\
\text { (kg ha }\end{array}$ & \multicolumn{3}{l}{ Number of grain in spike } & \multicolumn{4}{c}{ Weight of the grain $(\mathbf{g})$} \\
\hline 0 & Ch & Co & Le & Mean & Ch & Co & Le & Mean \\
\hline 80 & 45.38 & 48.25 & 46.33 & 46.65 & 1.98 & 2.16 & 2.12 & 2.09 \\
\hline 160 & 47.38 & 49.05 & 46.38 & 47.60 & 2.12 & 2.12 & 2.06 & 2.10 \\
\hline 240 & 48.13 & 47.70 & 49.78 & 48.53 & 2.08 & 2.09 & 2.23 & 2.13 \\
\hline Mean & 45.15 & 47.33 & 48.43 & 46.97 & 1.96 & 2.00 & 2.07 & 2.01 \\
\hline
\end{tabular}

Ch: Chemical, Co: Compost, Le: Leonardite

Similar to our research findings, Mert et al. (2003) stated that the effects of $\mathrm{N}$ doses on grain weight were statistically insignificant and inferred that $\mathrm{N}$ was primarily required for vegetative growth and had an insignificant effect on the reproductive growth of wheat plants. Contrary to 
our findings, Dokuyucu et al. (1999) reported that $\mathrm{N}$ doses significantly improved grain weight and higher $\mathrm{N}$ doses resulted in Hussain et al. (2012) determining that increasing nitrogen doses are directly proportional to the weight of the grain per spike.

\section{Thousand-grain weight (TGW)}

According to the result of the variance analysis of the TGW, the fertiliser form and the fertiliser form $\times$ nitrogen dose interaction was found to bestatistically insignificant. Differences between doses were significant at the $0.1 \%$ level (Table 6). TGW varied between 35.11-42.68 g. The highest TGW was registered at the dose of $160 \mathrm{~kg} \mathrm{~N} \mathrm{ha}{ }^{-1}$ (42.68 g) chemical fertiliser. The lowest TGW was determined at the dose of $80 \mathrm{~kg} \mathrm{~N}^{-1}$ $(35.11 \mathrm{~g})$ chemical fertiliser (Table 7).

Similar to our study, many researchers stated that the effects of nitrogen doses on TGW were statistically significant (Gerba et al., 2013) and Kizilgeci et al. (2021) showed that the effects of nitrogen doses on TGW were insignificant. Yıldırım et al. (2005) stated that the post-heading environmental conditions in wheat are more highly significant in TGW of better-performing varieties.

\section{Grain yield}

The wheat grain yield was not statistically affected by forms of fertilisers (Table 6). Grain yield varied between 3370.5 and $4961.9 \mathrm{~kg} \mathrm{ha}^{-1}$. The highest yield was registered in the $240 \mathrm{~kg} \mathrm{~N} \mathrm{ha}{ }^{-1}$ compost application $\left(4961.9 \mathrm{~kg} \mathrm{ha}^{-1}\right)$. The lowest yield was $3370.5 \mathrm{~kg} \mathrm{ha}^{-1}$ in the $0 \mathrm{~kg} \mathrm{~N} \mathrm{ha}{ }^{-1}$ compost application (Table 7). In our study, the grain yield increased as the nitrogen dose application increased. In the average of all fertiliser forms, the highest yield was registered at the dose of the $160 \mathrm{~kg}$ nitrogen. The highest yield value was determined in the $240 \mathrm{~kg}$ nitrogen composted manure. These findings are in contradiction with previous research results, whereby $\mathrm{N}$ doses significantly improved grain yield of wheat and higher $\mathrm{N}$ doses resulted in more vigorous growth of crop plants, where wheat yield was ultimately increased by 23\% (Başar and ark., 1998; Altuntaş and Akgün, 2016; Coşkun and Öktem, 2003; Atar and Akman, 2014; Avcı Birsin, 2001). However, Aydoğan Çifci and Doğan (2013) reported that the effects of $\mathrm{N}$ doses on grain yield were statistically insignificant. Kizilgeci et al. (2015) stated that despite optimal $\mathrm{N}$ doses, an insufficient amount of precipitation restricted plant growth and wheat yield, and thus $\mathrm{N}$ application rates must be studied in cohesion with soil moisture contents.

\section{Hectolitre weight}

Differences between $\mathrm{N}$ doses were significant at the $0.1 \%$ level for the hectolitre weight of wheat (Table 6). As per the findings of our study, the hectolitre weight varied between 79.10 and $81.83 \mathrm{~kg}$. The highest hectolitre weight was obtained in the application of $240 \mathrm{~kg} \mathrm{~N} \mathrm{ha}^{-1}$ $(81.83 \mathrm{~kg})$ chemical fertiliser. The lowest hectolitre weight was determined for the $0 \mathrm{~kg} \mathrm{~N} \mathrm{ha}{ }^{-1}(79.10 \mathrm{~kg})$ leonardite application (Table 7). Similar to our study, many researchers stated that the effect of nitrogen doses 
on hectolitre weight was statistically insignificant (Özseven, 1995; Avcı Birsin, 2007) and Kizilgeci et al. (2021) stated that the effect of nitrogen doses on hectolitre weight is important. It has been stated that the fullness, density, size, shape and homogeneity of the grain affect the hectolitre weight (Özkaya et al., 2018) and that the endosperm layer is higher in the varieties with high hectolitre weights (Şahin et al., 2017).

\section{Protein content}

According to the variance analysis results for protein content, the fertiliser form and fertiliser form $\times \mathrm{N}$ dose was found to be statistically insignificant. Differences between $\mathrm{N}$ doses were found to be significant at the $1 \%$ level (Table 8 ).

Similar to our study, many researchers stated that the protein content was significantly affected by nitrogen doses (Kizilgeci et al., 2015). The most common criterion in determining wheat quality is the amount of protein. It has been stated that the amount of grain protein is affected by environmental conditions, cultivation technique and genetic characteristics of the variety (Erekul et al., 2016).
The protein ratio varied between 14.28 and $18.03 \%$. The highest protein ratio was registered at the dose of 240 $\mathrm{kg} \mathrm{N}$ ha ${ }^{-1}$ chemical fertiliser $(18.03 \%)$. The lowest protein content was found in the $0 \mathrm{~kg} \mathrm{~N} \mathrm{ha}{ }^{-1}$ compost application $(14.28 \%)$ (Table 9). The increase in nitrogen dose caused an increase in protein content.

\section{Starch content}

Differences between $\mathrm{N}$ doses were found to be significant at the $1 \%$ level as far as starch content of wheat was concerned (Table 8). Under varying treatments, the starch ratio varied between 64.65 and $67.05 \%$. The highest starch ratio was obtained in the $0 \mathrm{~kg} \mathrm{~N} \mathrm{ha}{ }^{-1}$ compost application $(67.05 \%)$. The lowest starch ratio was determined in the application of $240 \mathrm{~kg} \mathrm{~N} \mathrm{ha}{ }^{-1}$ chemical fertiliser $(64.65 \%)$ (Table 9). Similar to our research, Kizilgeci et al. (2021) stated that $\mathrm{N}$ doses were statistically significant for starch content. It has been stated that the role of food products prepared from flour is less effective than proteins in the form of gluten, and the properties of starch are less affected by varieties and different growing conditions.

Table 6 - Analysis of variance (Mean squares) for yield, hectolitre weight, thousandgrain yield at different fertiliser forms and nitrogen dose applications to durum wheat

\begin{tabular}{lllll}
\hline Source & Df & Grain yield & Hectolitre weight & Thousand-grain weight \\
\hline Replication & 3 & 4302.29 & 0.7506 & 7.996 \\
\hline $\mathrm{FF}$ & 2 & 4451.36 & 0.769 & 3.4925 \\
\hline $\mathrm{N}$ & 3 & $34823.66^{\star \star *}$ & $9.5744^{\star \star *}$ & $59.9881^{\star \star *}$ \\
\hline $\mathrm{FF} \times \mathrm{N}$ & 6 & 4653.17 & 0.7134 & 5.9481 \\
\hline Error & 33 & 93044.65 & 31.85 & 219.2 \\
\hline $\mathrm{CV}(\%)$ & & 12.18 & 1.14 & 6.68 \\
\hline
\end{tabular}

***: $0.1 \%$ level of significance, FF: Fertiliser form,

$\mathrm{N}$ : Nitrogen dose, CV: coefficient of variation 
Mazlum AYHAN, Ferhat KIZILGEÇi, Muhammad Aamir IQBAL

Table 7 - Average values of grain yield, hectolitre weight, thousand-grain yield in different fertiliser forms and nitrogen doses applied to durum wheat

\begin{tabular}{|c|c|c|c|c|c|c|c|c|c|c|c|c|}
\hline \multirow{2}{*}{$\begin{array}{l}\mathrm{N} \\
\text { Doses } \\
\left.\text { (kg ha }^{-1}\right)\end{array}$} & \multicolumn{4}{|c|}{ Yield $\left(\mathrm{kg} \mathrm{ha}^{-1}\right)$} & \multicolumn{4}{|c|}{ Hectolitre weight $\left(\mathrm{kg} \mathrm{h}^{-1}\right)$} & \multicolumn{4}{|c|}{ Thousand grain weight (g) } \\
\hline & Ch & Co & Le & Mean & Ch & Co & Le & Mean & Ch & Co & Le & Mean \\
\hline 0 & 3858.0 & 3370.5 & 3856.8 & $3695.1 \mathrm{c}$ & 81.80 & 81.50 & 81.83 & $81.71 a$ & 35.56 & 36.89 & 37.87 & $36.80 c$ \\
\hline 80 & 4008.8 & 3641.2 & 4794.9 & $4148.3 b$ & 80.70 & 80.63 & 80.25 & $80.53 b$ & 35.11 & 37.41 & 37.97 & $36.80 c$ \\
\hline 160 & 4775.4 & 4856.4 & 4867.4 & $4833.1 \mathrm{a}$ & 79.43 & 79.93 & 80.23 & $79.86 \mathrm{~b}$ & 42.68 & 40.86 & 40.84 & $41.50 a$ \\
\hline 240 & 4685.6 & 4961.9 & 4632.0 & $4759.8 a$ & 79.10 & 79.75 & 80.48 & $79.78 b$ & 38.72 & 40.04 & 38.72 & $39.20 b$ \\
\hline Mean & 4331.9 & 4207.5 & 4759.8 & & 80.26 & 80.45 & 80.69 & & 38.00 & 38.80 & 38.84 & \\
\hline
\end{tabular}

Values followed by lowercase are significantly different, Ch: Chemical, Co: Compost, Le: Leonardite

Table 8 - Analysis of variance (mean squares) for protein content, starch content and wet gluten with different fertiliser forms and nitrogen dose applications to durum wheat

\begin{tabular}{lllll}
\hline Source & Df & Protein content & Starch content & Wet Gluten \\
\hline Replication & 3 & 1.5274 & 0.629444 & 8.5672 \\
\hline FF & 2 & 0.1415 & 0.290833 & 0.7108 \\
\hline $\mathrm{N}$ & 3 & $21.1024^{\star * *}$ & $8.453889^{\star * * *}$ & $115.4406^{\star * *}$ \\
\hline FF x N & 6 & 0.797 & 0.326389 & 4.3247 \\
\hline Error & 33 & 24.55 & 11.25 & 134.04 \\
\hline CV $(\%)$ & & 5.24 & 0.88 & 5.28 \\
\hline
\end{tabular}

${ }^{* * *}: 0.1 \%$ level of significance FF: Fertiliser form, $\mathrm{N}$ : Nitrogen dose, CV: coefficient of variation

Table 9 - Average values of protein content, starch content and wet gluten in different fertiliser forms and nitrogen doses application to durum wheat

\begin{tabular}{|c|c|c|c|c|c|c|c|c|c|c|c|c|}
\hline \multirow{2}{*}{$\begin{array}{l}\mathbf{N} \\
\text { Doses } \\
\left.\text { (kg ha }^{-1}\right) \\
\end{array}$} & \multicolumn{4}{|c|}{ Protein content (\%) } & \multicolumn{4}{|c|}{ Starch content (\%) } & \multicolumn{4}{|c|}{ Wet Gluten (\%) } \\
\hline & $\mathrm{Ch}$ & Co & Le & Mean & Ch & Co & Le & Mean & $\mathrm{Ch}$ & Co & Le & Mean \\
\hline 0 & 14.38 & 14.28 & 15.00 & $14.55 \mathrm{c}$ & 67.03 & 67.05 & 66.75 & $66.94 a$ & 33.38 & 33.10 & 34.80 & $33.76 \mathrm{c}$ \\
\hline 80 & 16.35 & 16.38 & 16.68 & $16.50 \mathrm{~b}$ & 65.83 & 65.90 & 65.68 & $65.80 \mathrm{~b}$ & 37.90 & 37.95 & 38.75 & $38.20 \mathrm{~b}$ \\
\hline 160 & 17.43 & 17.63 & 16.98 & $17.30 \mathrm{a}$ & 64.95 & 65.13 & 65.50 & $65.19 \mathrm{c}$ & 40.50 & 40.98 & 39.48 & $40.32 a$ \\
\hline 240 & 18.03 & 17.23 & 16.90 & $17.40 \mathrm{a}$ & 64.65 & 65.23 & 65.53 & $65.13 c$ & 41.83 & 40.03 & 39.23 & 40.36 \\
\hline Mean & 16.54 & 16.39 & 16.38 & & 65.61 & 65.83 & 65.86 & & 38.40 & 38.01 & 38.06 & \\
\hline
\end{tabular}

Values followed by lowercase are significantly different, Ch: Chemical, Co: Compost, Le: Leonardite

\section{Wet gluten}

For wet gluten contents, the differences between nitrogen doses were found to be significant at the $0.1 \%$ level (Table 8). The wet gluten ratio varied between 33.10 and $41.83 \%$. The highest wet gluten ratio was registered at the dose of $240 \mathrm{~kg} \mathrm{~N} \mathrm{ha}^{-1}$ chemical fertiliser (41.83). The lowest wet gluten rate was found in the
$0 \mathrm{~kg} \mathrm{~N} \mathrm{ha}{ }^{-1}$ compost application (33.10) (Table 9). Similar to our study (Öztürk and Gökkuş, 2008; Kara et al., 2009), the effects of nitrogen doses on gluten ratio were statistically significant. Gluten consists of glutenin and gliadin proteins. Gluten is an elastic prolamin group protein that shows the dough's suitability for bread making. 


\section{Normalised difference vegetation index (NDVI)}

\section{Heading stage}

At the heading stage, a statistically significant interaction of fertiliser form and the fertiliser form $\times$ nitrogen dose interaction were found, while the differences between nitrogen doses were found to be significant at the level of $0.1 \%$ (Table 10). Heading stage NDVI values varied between 0.72 and 0.83 . The highest heading period NDVI rate was obtained in the $240 \mathrm{~kg} \mathrm{~N} \mathrm{ha}{ }^{-1}$ application of compost (0.83) and chemical fertilisers. The lowest heading period NDVI rate was determined in the $0 \mathrm{~kg} \mathrm{~N} \mathrm{ha}{ }^{-1}$ compost application (0.72) (Table 11). In a similar study, Kizilgeci et al. (2021) stated that the NDVI values increased during the head period as the nitrogen dose increased. They also reported that NDVI values between 0.59 and 0.66 were obtained during the heading stage in their research, in which they tried to establish the effects of various nitrogen dosages on the NDVI values of durum wheat varieties.

\section{Anthesis stage}

According to the variance analysis result of the NDVI values measured during the anthesis stage, the fertiliser form and the fertiliser form $x$ nitrogen dose interaction were not statistically significant. Only the differences between nitrogen doses were significant at the 5\% level (Table 10). The NDVI value in anthesis for the applications varied between 0.70 and 0.80 . The highest anthesis NDVI value was obtained in the $240 \mathrm{~kg} \mathrm{~N}$ ha $^{-1}$ compost application (0.70). The lowest anthesis NDVI rate was detected in the $80 \mathrm{~kg} \mathrm{~N} \mathrm{ha}{ }^{-1}$ leonardite application (0.80) (Table 11).

Similarly, Kızılgeçi et al. (2021) reported that there was a difference between the NDVI values measured during the flowering period. NDVI values increased with the increase in nitrogen dose. Since NDVI values are an indicator of the health of the plant, it is thought that the differences in NDVI values are because the plant is greener at a high nitrogen dose.

\section{Milk stage}

The analysis table obtained from the application of different nitrogen forms and fertiliser doses relative to the NDVI values measured in the milk stage is given in Table 10. Statistically, the fertiliser forms, and nitrogen dose were insignificant, but the differences between nitrogen doses were significant at the $1 \%$ level. NDVI values varied between 0.63 and 0.71 in the milk stage. The highest NDVI value was obtained from the $80 \mathrm{~kg} \mathrm{~N}^{-1}$ and $160 \mathrm{~kg} \mathrm{~N} \mathrm{ha}^{-1}$ compost, as well as $160 \mathrm{~kg} \mathrm{~N} \mathrm{ha}{ }^{-1}$ leonardite applications (0.71) (Table 11).

Savas et al. (2012) in their study on the evaluation of bread wheat lines in terms of grain yield and NDVI; stated that they determined a significant relationship between the vegetation index of the milky stage of bread wheat and grain yield in dry conditions and supplementary irrigation, but they did not detect any relationship in irrigated conditions.

\section{Dough stage}

According to the variance analysis results for the NDVI values 
measured in the dough stage, while the fertiliser form and the fertiliser form $x$ nitrogen dose interaction were found to be insignificant, the differences between nitrogen doses were significant at the 5\% level (Table 10). Kizilgeci (2021) stated that there is a positive and significant relationship between NDVI values obtained in the dough stage in durum wheat. NDVI values ranged between 0.39 and 0.56 . The highest NDVI value was obtained in the $80 \mathrm{~kg} \mathrm{~N} \mathrm{ha}^{-1}$ compost application (0.56). The lowest NDVI value was detected in the $160 \mathrm{~kg} \mathrm{~N} \mathrm{ha}^{-1}$ compost application (0.39) (Table 11).

\section{Relationship between wheat} development stages and NDVI values

The NDVI values measured in different stages generally had similar values in fertiliser forms and fertiliser doses during the heading and anthesis stages. While the maximum decrease in NDVI value between the heading and dough stage was determined at the $160 \mathrm{~kg}$ nitrogen dose of composted manure, the lowest decrease was determined at the $80 \mathrm{~kg}$ nitrogen dose of composted manure (Fig. 3).

Table 10 - Analysis of variance (mean squares) for NDVI with different fertiliser forms and nitrogen dose applications to durum wheat

\begin{tabular}{llllll}
\hline Source & Df & Heading & Anthesis & Milk & Dough \\
\hline Replication & 3 & 0.0014 & 0.0004 & 0.0046 & 0.0104 \\
\hline FF & 2 & 0.0006 & 0.0001 & 0.0022 & 0.0089 \\
\hline $\mathrm{N}$ & 3 & $0.0125^{\star * *}$ & $0.0044^{\star \star *}$ & $0.0072^{\star *}$ & $0.0154^{*}$ \\
\hline FF $\times \mathrm{N}$ & 6 & 0.0013326 & 0.00025 & 0.0013854 & 0.0071201 \\
\hline Error & 33 & 0.048 & 0.023 & 0.05 & 0.147 \\
\hline $\mathrm{CV}(\%)$ & & 4.80 & 3.43 & 5.77 & 1.44 \\
\hline
\end{tabular}

${ }^{* * *},{ }^{* *},{ }^{*}: 5 \%, 1 \%, 0.1 \%$ level of significance respectively, FF: Fertiliser form, $\mathrm{N}$ : Nitrogen dose, CV: coefficient of variation

Table 11 - Average values of NDVI with different fertiliser forms and nitrogen doses applied to durum wheat

\begin{tabular}{|c|c|c|c|c|c|c|c|c|}
\hline \multirow{2}{*}{ Doses (N kg ha ${ }^{-1}$ ) } & \multicolumn{4}{|c|}{ Heading } & \multicolumn{4}{|c|}{ Anthesis } \\
\hline & Ch & Co & Le & Mean & Ch & Co & Le & Mean \\
\hline 0 & 0.75 & 0.72 & 0.79 & $0.75 b$ & 0.75 & 0.74 & 0.76 & $0.75 b$ \\
\hline 80 & 0.80 & 0.80 & 0.80 & $0.80 a$ & 0.77 & 0.78 & 0.70 & $0.77 a$ \\
\hline 160 & 0.82 & 0.82 & 0.81 & $0.82 a$ & 0.79 & 0.79 & 0.79 & $0.79 a$ \\
\hline 240 & 0.83 & 0.83 & 0.82 & $0.82 a$ & 0.79 & 0.80 & 0.79 & $0.79 a$ \\
\hline Mean & 0.80 & 0.79 & 0.80 & & 0.78 & 0.78 & 0.78 & \\
\hline \multirow{2}{*}{ Doses (N kg ha $\left.{ }^{-1}\right)$} & Milk & \multicolumn{7}{|c|}{ Dough } \\
\hline & $\mathrm{Ch}$ & Co & Le & Mean & Ch & Co & Le & Mean \\
\hline 0 & 0.63 & 0.64 & 0.66 & $0.64 b$ & 0.41 & 0.43 & 0.50 & $0.44 \mathrm{~b}$ \\
\hline 80 & 0.67 & 0.71 & 0.69 & $0.69 a$ & 0.47 & 0.56 & 0.50 & $0.51 a$ \\
\hline 160 & 0.66 & 0.66 & 0.71 & $0.68 a$ & 0.41 & 0.39 & 0.48 & $0.43 b$ \\
\hline 240 & 0.70 & 0.71 & 0.69 & $0.70 a$ & 0.46 & 0.52 & 0.45 & $0.48 a b$ \\
\hline Mean & 0.66 & 0.68 & 0.69 & & 0.44 & 0.47 & 0.48 & \\
\hline
\end{tabular}

Values followed by lowercase are significantly different,

Ch: Chemical, Co: Compost, Le: Leonardite 


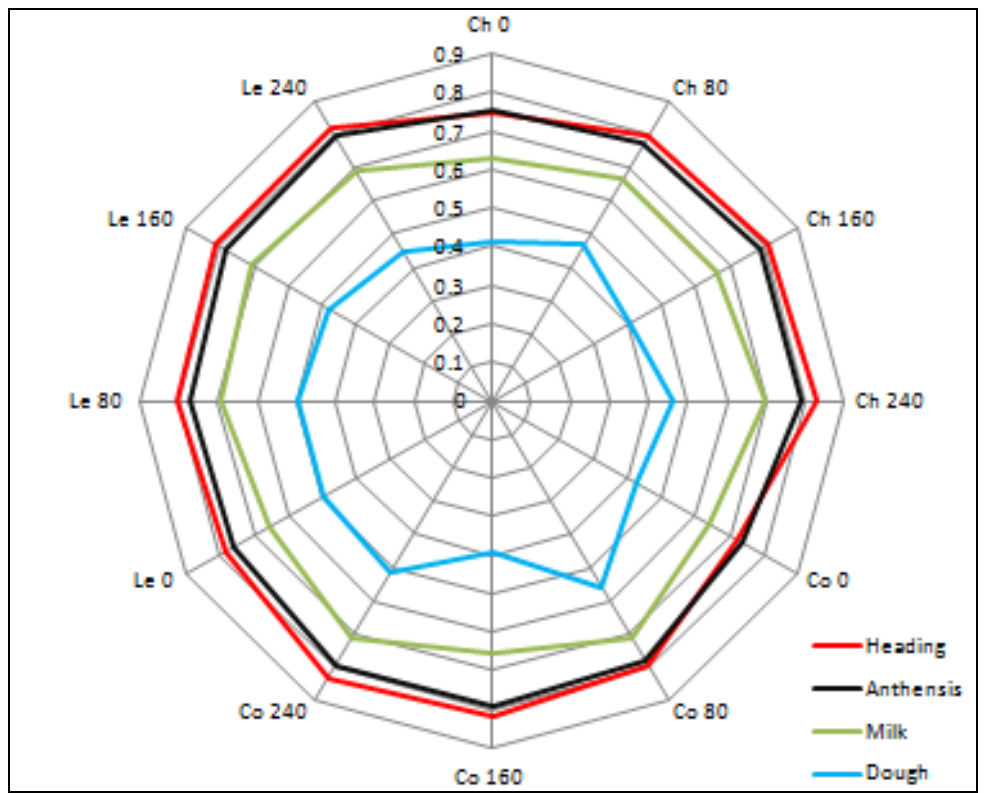

Figure 3 - Radar chart of NDVI values measured in different periods

\section{CONCLUSIONS}

Our research findings were not in line with the postulated hypothesis, as the effects of fertiliser forms, and nitrogen doses remained statistically at par with each other for height of the plant, length of the spike, spikelets number, number of grains in spike, grain weights. It was also determined that the fertiliser form and the fertiliser form $\times$ nitrogen dose interaction was insignificant for grain yield, hectolitre weight and thousand-grain weight. The protein content and wet gluten values increased in parallel with the increase in nitrogen dose. Starch content and hectolitre weight values decreased with increasing dose of $\mathrm{N}$. Thus, the effects of fertiliser forms on the examined properties should be similar under rain-fed conditions, and this study should be done under long-term and irrigated conditions to validate the results under varying pedo-climatic conditions.

\section{REFERENCES}

Ahmad, Z., Waraich, E.A., Tariq, R.M.S., Iqbal, M.A., Ali, S., Soufan, W., Hassan, M.M., Islam, M.S. \& Sabagh, A.L. (2021). Foliar applied salicylic acid ameliorates water and salt stress by improving gas exchange and photosynthetic pigments in wheat. Pak. J. Bot., 53(5): 1553-1560, DOI: 10.30848/ PJB2021-5(17)

Alam, M.A., Skalicky, M., Kabir, M.R., Hossain, M.M., Hakim, M.A., Mandal, M.S.N. et al. (2021). Phenotypic and molecular assessment of wheat genotypes tolerant to leaf blight, rust and blast diseases. Phyton.- Int. J Exp. Bot., 90(4): 1301-1320. DOI: 10.32604/ phyton.2021.016015

Alghawry, A., Yazar, A., Unlu, M., Çolak, Y.B., Iqbal, M.A., Barutcular, C. et 
al. (2021). Irrigation rationalization boosts wheat (Triticum aestivum L.) yield and reduces rust incidence under arid conditions. BioMed Res. Int., DOI:10.1155/2021/5535399

Altuntas, A. \& Akgun, I. (2016). Influence of different nitrogen dose and liquid fertilizer applications on yield and yield components of Kızıltan-91 wheat cultivar under Uşak conditions. S.D.U. J. Nat. Appl. Sci., 20(3): 496503. DOI: 10.19113/sdufbed.53037

Atar, B. \& Akman, Z. (2014). Effects of seed priming and nitrogen doses on grain yield and some yield components of bread wheat (Triticum aestivum L.) varieties. Ziraat Fakültesi Dergisi S.D.U., 9(2): 69-82.

Avci Birsin, M. (2001). Buğdayda farklı azot dozlarının tane verimi, protein oranı ve protein verimine etkisi. Tarim Bilimleri Dergisi, 7(1): 84-88.

Aydoğan Çifci, E. \& Doğan, R. (2013). The effects of nitrogen doses on yield and quality traits of Gediz-5 and Flamura-85 wheat varieties. Tarim Bilimleri Dergisi, 19: 1-11.

Başar, H., Tümsavas, Z., Katkat, A. V. \& Özgümüş, A. (1998). Effects of various nitrogen sources and the levels of nitrogen on yield and the yield components of the wheat cultivar Saraybosna. Turk. J. Agric. For., 22(1): 59-64.

Chowdhury, M.K.; M.A. Hasan, M.M. Bahadur, M.R. Islam, M.A. Hakim \& Muhammad Aamir lqbal (2021). Evaluation of drought tolerance of some wheat (Triticum aestivum L.) genotypes through phenology, growth, and physiological indices. Agron., 11(9): 1792, DOI: 10.3390/agronomy11091792

Coşkun, Y. ve Öktem, A. (2003). Farklı dozlarda ve zamanlarda uygulanan azotun makarnalık buğdayın verim ve verim unsurlarına etkisi. Harran Üniversitesi Ziraat Fakültesi Dergisi, 7(3-4): 1-10.

Dokuyucu, T., Cesurer, L. \& Akkaya, A. (1999). Investigation of yield and yield components of some bread wheat (Triticum aestivum L.) genotypes in Kahramanmaraş conditions. 3rd Field Crops Congress, Adana, Turkey, 15-20 November.

Erekul, O., Oncan, F., Erekul, A., Yava, I.., Engün, B. \& Koca, Y.O. (2005). Determination of yield and some quality characteristics in advanced bread wheat lines. VI Field Crops Congress, Antalya, Turkey, 5-9 September.

Erekul, O., Yiğit, A., Koca, Y.O., Ellmer, F. ve Wei, K. (2016). Bazı ekmeklik buğday (Triticum aestivum L.) Çeşitlerinin kalite potansiyelleri ve beslenme fizyolojisi açısından önemi. Tarla Bitkileri Merkezi Araştırma Enstitüsü Dergisi. 25 (Özel sayı): 3136.

Gerba, L., Getachew, B. \& Walelign, W. (2013). Nitrogen fertilization effects on grain quality of durum wheat (Triticum turgidum L. var. durum) varieties in central Ethiopia. Agric. Sci., 4(3): 123-130, DOI: 10.4236/as. 2013.43019

Gökmen, F., Zengin, M., Traveler, S., Arısoy, R.Z., Çakmak, İ. \& Taner, S. (2008). The effects of ammonium nitrate and entec fertilizers on yield and yield components of durum wheat grown in zinc-free and zinccontaining blocks. National Grain Symposium, Konya, Turkey, 2-5 June.

Hussain, I., Khan, M.A. \& Khan, E.A. (2006). Bread wheat varieties as influenced by different nitrogen levels. J. Zhejiang Univ. Sci. B., 7(1): 70-78, DOI: 10.1631/jzus.2006. B0070

Iqbal, M.A., Imtiaz H., Abdul, H., Bilal A., Saira, I., Ayman, S., Celaleddin, B., Rana, D.K. \& Imran, M. (2021a). Soybean herbage yield, nutritional value and profitability under integrated manures management. An. Acad. Bras. Cienc., 93(1), DOI: 10.1590/0001-3765202120181384

Iqbal, M.A., Rahim, J., Naeem, W., Hassan, S., Khattab, Y. \& Sabagh, A.E.L. (2021b). Rainfed winter wheat 


\section{FERTILISATION SOURCE AND DOSE OPTIMISATION BOOST YIELD OF DURUM WHEAT}

(Triticum aestivum L.) cultivars respond differently to integrated fertilization in Pakistan. Fresenius Environ. Bull., 30(4): 3115-3121.

Kara B., Halef, D., Uysal, N. ve Gul, H. (2009). Buğdayda geç dönemde azot uygulamasının tane protein ve unda bazı fizikokimyasal özelliklere etkisi. Süleyman Demirel Üniversitesi Fen Bilimleri Enstitüsü Dergisi, 13(1): 2532.

Kara, B. ve Gül, H. (2013). Alternatif gübrelerin farklı ekmeklik buğday çeşitlerinin tane verimi, verim komponentleri ve kalite özelliklerine etkileri. Süleyman Demirel Üniversitesi Ziraat Fakültesi Dergisi, 8(2): 88-97.

Kizilgeci, F., Yildirim, M., Akinci, C., Albayrak, Ö. ve Başdemir, F. (2015). İleri kademe makarnalık buğday popülasyonlarının verim ve kalite yönünden seleksiyonda kullanılabilirliği. Ziraat Fakültesi Dergisi, 10(2): 62-68.

Kizilgeci, F. (2019). Physiological, agronomical and quality response of bread wheat to phosphorus application under dryland condition. Appl. Ecol. Env. Res., 17(2): 19791987. DOI: 10.15666/aeer/1702_19 791987

Kizilgeci F., Yildirim, M., Islam, M.S., Ratnasekera, D., lqbal, M.A. \& Sabagh, A.E.L. (2021). Normalized difference vegetation index and chlorophyll content for precision nitrogen management in durum wheat cultivars under semi-arid conditions. Sustainability, 13(7): 3725, DOI: 10.3390/su13073725

Namlı, A., Akça, M. O. ve Hanife, A.K.Ç.A. (2019). Afşin-Elbistan havzası linyit işletmesi organik materyallerinden geliştirilen organik ve organomineral gübrelerin buğday verimi ve verim bileşenleri ile bazı toprak özellikleri üzerine etkileri. Toprak Bilimi ve Bitki Besleme Dergisi, 7(1): 10-20, DOI: 10.33409/ tbbbd.594998

Özseven, İ. (1995). Ekmeklik buğday (Triticum aestivum var aestivum L.) çeşitlerinde azotun verim ve verim öğelerine etkisi. Yüksek Lisans Tezi, Bursa Uludağ Üniversitesi, Fen Bilimleri Enstitüsü, Bursa, Türkiye.

Özkaya, B., Turksoy, S., Özkaya, H., Baumgartner, B., Özkeser, î. \& Köksel, H. (2018). Changes in the functional constituents and phytic acid contents of firiks produced from wheats at different maturation stages. Food Chem., 246: 150-155, DOI: 10.1016/j.foodchem.2017.11.022

Öztürk, İ. \& Korkut, K.Z. (2018). Drought effects on yield and yield components in different growing periods of some bread wheat (Triticum aestivum L.) genotypes. Journal of Tekirdag Agricultural Faculty, 15(2): 128-137.

Öztürk, İ. \& Gökkuş, A. (2008). The effects of nitrogen fertilization on grain yield and quality in some bread wheat varieties. Journal of Agricultural Sciences (Turkey), 14(4): 334-340.

Sade, B., Topal, A. \& Soylu, S., (1999). Determination of durum wheat varieties that can be grown in Konya conditions. Problems of Grain Agriculture in Central Anatolia and Solutions. Symposium, Konya, Turkey, 8-11 June.

Siddiqui, M.H., Iqbal, M.A., Naeem, W., Hussain, I. \& Khaliq, A. (2019). Bioeconomic viability of rainfed wheat (Triticum aestivum L.) cultivars under integrated fertilization regimes in Pakistan. Custos e Agronegocio, 15(3): 81-96.

Sullivan, M., Khalilian, A., Mueller, J., Wolak, F., Willianson, R. \& Lippert, R. (1998). Composted municipal solid waste application impacts on cotton yield and soil properties. In: Composting in the Southeast 1998 Conference Proceedings, Memphis, USA.

Şahin, M., Akçacik, A.G., Aydoğan, S., Hamzaoğlu, S., Demir, B. ve Yakişir, E. (2017). Kışlık ekmeklik buğday çeşitlerinde zeleny sedimantasyon ile verim ve bazı kalite özellikleri arasındaki ilişkilerin 
Mazlum AYHAN, Ferhat KIZILGEÇi, Muhammad Aamir IQBAL

incelenmesi. Bahri Dağdaş Bitkisel Araştırma Dergisi, 6(1): 10-21.

Uyanöz, R., Çetin, Ü. ve Karaaslan, E., (2004). Çeşitli organik materyallerin buğday bitkisinin mineral madde alımı üzerine etkisi. Selçuk Üniversitesi Ziraat Fakültesi Dergisi, 18(34): 20-27.

Yazar, S. \& Karadogan, T. (2018). Determination of the yield and quality traits of some durum wheat genotypes under the lowland and aridland conditions of Central Anatolian Region. Süleyman Demirel Üniversitesi Ziraat Fakültesi Dergisi, 3(2): 32-41, Isparta.

Yıldırım, A., Sakin, M. A. ve Gökmen, S. (2005). Tokat Kazova koşullarında bazı ekmeklik buğday çeşit ve hatlarının verim ve verim unsurları yönünden değerlendirilmesi. Gaziosmanpaşa Üniversitesi Ziraat Fakültesi Dergisi, 22(1): 63-72 